OPEN ACCESS

Edited by:

Gary McLean,

Imperial College London,

United Kingdom

Reviewed by:

Arun Kumar,

Linköping University, Sweden

Jürgen Hausmann,

Bavarian Nordic, Germany

*Correspondence:

Eric J. Gowans

eric.gowans@adelaide.edu.au

Specialty section:

This article was submitted to

Infectious Diseases,

a section of the journal

Frontiers in Microbiology

Received: 30 August 2017 Accepted: 22 November 2017 Published: 05 December 2017

Citation: Masavuli MG, Wijesundara DK,

Torresi J, Gowans EJ and Grubor-Bauk B (2017) Preclinical Development and Production of Virus-Like Particles As Vaccine

Candidates for Hepatitis C.

Front. Microbiol. 8:2413. doi: 10.3389/fmicb.2017.02413

\section{Preclinical Development and Production of Virus-Like Particles As Vaccine Candidates for Hepatitis C}

\author{
Makutiro Ghislain Masavuli', Danushka K. Wijesundara ${ }^{1}$, Joseph Torresi², \\ Eric J. Gowans ${ }^{1 *}$ and Branka Grubor-Bauk ${ }^{1}$ \\ 'Virology Laboratory, Basil Hetzel Institute for Translational Medicine, Discipline of Surgery, University of Adelaide, Adelaide, \\ SA, Australia, ${ }^{2}$ Department of Microbiology and Immunology, The Peter Doherty Institute for Infection and Immunity, \\ University of Melbourne, Parkville, VIC, Australia
}

Hepatitis C Virus (HCV) infects $2 \%$ of the world's population and is the leading cause of liver disease and liver transplantation. It poses a serious and growing worldwide public health problem that will only be partially addressed with the introduction of new antiviral therapies. However, these treatments will not prevent re-infection particularly in high risk populations. The introduction of a HCV vaccine has been predicted, using simulation models in a high risk population, to have a significant effect on reducing the incidence of HCV. A vaccine with 50 to $80 \%$ efficacy targeted to high-risk intravenous drug users could dramatically reduce HCV incidence in this population. Virus like particles (VLPs) are composed of viral structural proteins which self-assemble into non-infectious particles that lack genetic material and resemble native viruses. Thus, VLPs represent a safe and highly immunogenic vaccine delivery platform able to induce potent adaptive immune responses. Currently, many VLP-based vaccines have entered clinical trials, while licensed VLP vaccines for hepatitis B virus (HBV) and human papilloma virus (HPV) have been in use for many years. The HCV core, E1 and E2 proteins can self-assemble into immunogenic VLPs while inclusion of HCV antigens into heterogenous (chimeric) VLPs is also a promising approach. These VLPS are produced using different expression systems such as bacterial, yeast, mammalian, plant, or insect cells. Here, this paper will review HCV VLP-based vaccines and their immunogenicity in animal models as well as the different expression systems used in their production.

Keywords: viral hepatitis, hepatitis C virus, preventative vaccination, virus-like particles, immune response, liver disease

\section{INTRODUCTION}

Hepatitis C Virus is an enveloped positive sense single-stranded RNA virus that infects more than 170 million people ( $\sim 2 \%$ of the world's population) (Bartenschlager et al., 2011). A majority of the individuals infected with HCV develop chronic hepatitis and a proportion will develop cirrhosis and liver carcinoma. HCV remains the most common reason for liver transplantation worldwide (Bartenschlager et al., 2011).

The introduction of highly effective direct acting antivirals (DAA) designed to inhibit the function of specific non-structural (NS) viral proteins critical to viral replication has resulted in high cure rates in most patients, a shortened duration of treatment and is associated with relatively 
few side effects. However, the use of DAA is limited by the high cost (up to US\$147,000 for 12-week treatment course) (Ahlén et al., 2013; Rosenthal and Graham, 2016). As a consequence, it is estimated that approximately $\sim 1 \%$ of those diagnosed with hepatitis $C$ virus infection are treated annually in Australia (Commonwealth of Australia, 2014), while the global pool of HCV infected persons is increased by 3-4 million new infections each year (Gower et al., 2014). Furthermore, the World Health Organization (WHO) estimates that as of 2015 only $20 \%$ of those infected with HCV were aware of their diagnosis and only $7.4 \%$ of those diagnosed with HCV were placed on treatment worldwide (World Health Organization, 2017). Consequently, developing a safe, effective and inexpensive HCV vaccine is therefore necessary to control global infection and reduce the financial burden on healthcare systems.

However, the development of an effective HCV vaccine is hindered by several factors including the high genetic variability of the virus genome that gives rise to escape mutants which can evade both cellular and humoral host immune responses. Moreover, currently there are no suitable small animal models available that can mimic HCV infection of humans. Furthermore, humans and chimpanzees who have been previously treated and cured of hepatitis $\mathrm{C}$ could be re-infected after re-exposure to the virus (Farci et al., 1992; Bukh et al., 2008). Conversely, there is some optimism that the development of a successful $\mathrm{HCV}$ vaccine might be possible because a proportion of infected individuals (15-25\%) clear the virus naturally and develop some immunity that is able to reduce the duration of viremia and the viral load in subsequent infections (Prince, 1994; Halliday et al., 2011). An understanding of the antiviral immune responses in these individuals and in the chimpanzee model have elucidated key mechanisms thought to contribute to the control of HCV infection. It was demonstrated that the induction and maintenance of strong $\mathrm{CD} 4++$ and $\mathrm{CD} 8+\mathrm{T}$ cell immune responses against various viral epitopes are associated with the resolution of HCV infection (Forns et al., 2000; Thimme et al., 2001, 2002; Youn et al., 2005). It is now thought that a cellmediated response alone is not sufficient and that the timely induction of cross-neutralizing antibodies (NAbs) is important for protection and in viral clearance (Farci et al., 1996; Yu et al., 2004; Osburn et al., 2014).

Licensed viral vaccines such as poliovirus, induce NAbs against viral surface proteins to provide protection. However, despite the development of an efficient system for HCV culture (Lindenbach et al., 2005; Wakita et al., 2005; Zhong et al., 2005), it is still not feasible to generate a vaccine based on killed or liveattenuated $\mathrm{HCV}$ due to the potential dangers associated with the use of such particles (Forns et al., 2002). These shortcomings have led to the development of experimental vaccines which include DNA vaccines, recombinant (non-pathogenic) vectors, proteins and virus like particles (VLPs). Despite the many obstacles that impede the development of these vaccines, several studies involving VLP-based vaccine candidates have already generated promising results in preclinical studies (Murata et al., 2003; Jourdan et al., 2006; Elmowalid et al., 2007; Patient et al., 2009; Roy and Noad, 2009; Garrone et al., 2011; Vicente et al., 2011; Bellier and Klatzmann, 2013; Huret et al., 2013; Beaumont and
Roingeard, 2015). This article will review HCV vaccine strategies based on homologous or heterologous HCV VLPs (Table 1), plasmid DNA and viral vectors encoding HCV-VLPs (Table 2) as well as various expression systems (Table 3 ) utilized in the production of HCV VLP vaccines.

\section{HCV VLP VACCINES IN PRE-CLINICAL STUDIES}

\section{HCV-Derived VLPs}

Virus like particles are attractive candidates to elicit NAb responses as they structurally resemble and are much safer than the wild-type virus from which they are derived (Jourdan et al., 2006; Torresi et al., 2007; Roy and Noad, 2009). In addition to the hepatitis B virus (HBV) and HPV VLP vaccines, the VLP approach has been used to recently develop a chikungunya virus vaccine that was effective in non-human primates (Akahata et al., 2010). Self-assembled core-E1-E2 HCV-like particles (HCV-LPs) have been reported to generate HCV-VLPs with biophysical, ultrastructural and antigenic properties similar to those of the putative virion (Baumert et al., 1998, 1999). These HCV-LPs were generated in Sf9 cells from recombinant baculovirus encoding the HCV core, E1 and E2 proteins. Immunization with these recombinant $\mathrm{HCV}$-LPs revealed that they can induce strong and broad polyclonal cellular and humoral immunity in mice (Baumert et al., 1999; Lechmann et al., 2001; Murata et al., 2003) as well as in chimpanzees (Table 1) (Elmowalid et al., 2007). The immunogenicity of HCV-LPs is strongly dependent on particle formation because vaccination with heat-denatured particles resulted in reduced antigen-specific T-cell and antibody responses (Lechmann et al., 2001). It is proposed that HCV-LP have the ability to interact specifically with dendritic cells (DCs) resulting in their activation and efficient antigen presentation, in contrast to denatured HCV-LPs (Murata et al., 2003; Barth et al., 2005).

Hepatitis C Virus-LPs that were produced in mammalian cells using an adenovirus-based system generated particles which were reported to resemble the native virions morphologically (Chua et al., 2012; Kumar et al., 2016). Vaccination with these adenovirus-derived HCV-LPs in combination with an anionic self-adjuvanting lipopeptide containing the Toll-like receptor (TLR) 2 agonist $\mathrm{Pam}_{2} \mathrm{Cys}\left(\mathrm{E}_{8} \mathrm{Pam}_{2} \mathrm{Cys}\right)$ resulted in significant HCV-LP and E2-specific antibody responses mice (Chua et al., 2012). Up to three doses of non-adjuvanted or traditional alum-adjuvanted HCV-LPs were essential to reach similar HCV-LP- and E2-specific antibody titers induced with a single dose of $\mathrm{HCV}-\mathrm{LP}+\mathrm{E}_{8} \mathrm{Pam}_{2} \mathrm{Cys}$. In addition, these antibodies neutralized the binding and uptake of VLPs by human hepatocellular carcinoma (Huh-7) cells and of cell culture derived HCV (HCVcc). Significant numbers of antigen-specific antibody secreting cells were also detected in the spleen of HCV$\mathrm{LP}+\mathrm{E}_{8} \mathrm{Pam}_{2}$ Cys vaccinated mice, correlating with the previous results (Chua et al., 2012). Moreover, vaccination of human leukocyte antigen (HLA)-A2 transgenic mice with this vaccine generated higher HCV-LP-specific IFN- $\gamma$-mediated responses compared to non-adjuvanted HCV-LPs (Chua et al., 2012). 
TABLE 1 | Homologous and recombinant Hepatitis C Virus (HCV) virus-like particle vaccines.

\begin{tabular}{|c|c|c|c|c|c|c|}
\hline $\begin{array}{l}\text { Viral structural } \\
\text { components }\end{array}$ & $\begin{array}{l}\text { Expression } \\
\text { system }\end{array}$ & Cells & $\begin{array}{l}\text { Route of } \\
\text { administration }\end{array}$ & $\mathrm{HCV}$ antigen & Animal studies & Reference \\
\hline \multirow[t]{3}{*}{ HCV-core } & Insect cells & Sf-9 & $\begin{array}{l}\text { Intraperitoneal and } \\
\text { intramuscular }\end{array}$ & Core, E1, and E2 & $\begin{array}{l}\text { Mice and } \\
\text { chimpanzees }\end{array}$ & $\begin{array}{l}\text { Baumert et al., 1999; } \\
\text { Lechmann et al., 2001; } \\
\text { Murata et al., 2003; } \\
\text { Elmowalid et al., 2007 }\end{array}$ \\
\hline & Mammalian & Huh-7 & Subcutaneous & Core, E1, and E2 & Mice & Kumar et al., 2016 \\
\hline & Yeast & P. pastoris & Subcutaneous & Core, E1 and E2 & Rabbits & \\
\hline \multirow[t]{2}{*}{ HBcore } & Bacteria & E. coli (Gl698 cells) & Subcutaneous & $\begin{array}{l}\text { Core (98 aa) and } \\
\text { NS3 (155 aa) }\end{array}$ & Mice & Mihailova et al., 2006 \\
\hline & & E. coli (K802 cells) & Subcutaneous & $\begin{array}{l}\text { Core (60 aa) also } \\
\text { HBV-S1 ( } 27 \text { aa) }\end{array}$ & Mice & $\begin{array}{l}\text { Sominskaya et al., } \\
2010\end{array}$ \\
\hline \multirow[t]{2}{*}{ HBsAg } & Mammalian & Huh-7, HEK293T & Subcutaneous & E2 HVR-1 (36 aa) & Mice & $\begin{array}{l}\text { Netter et al., } 2001 \text {, } \\
2003 \text {; Vietheer et al., } \\
2007\end{array}$ \\
\hline & & $\mathrm{CHO}$ cells & Subcutaneous & $\mathrm{E} 1, \mathrm{E} 2$, and E1E2 & Rabbits & $\begin{array}{l}\text { Beaumont et al., 2013, } \\
\text { 2016; Beaumont and } \\
\text { Roingeard, } 2015\end{array}$ \\
\hline PapMV CP & Bacteria & E. coli & Subcutaneous & E2 & Mice & Denis et al., 2007 \\
\hline \multirow[t]{2}{*}{ MLV Gag } & Mammalian & HEK293T & $\begin{array}{l}\text { Subcutaneous, } \\
\text { intramuscular and } \\
\text { intradermal }\end{array}$ & $\mathrm{E} 1$ and E1E2 & $\begin{array}{l}\text { Mice and } \\
\text { macaques }\end{array}$ & $\begin{array}{l}\text { Desjardins et al., 2009; } \\
\text { Garrone et al., 2011; } \\
\text { Huret et al., } 2013\end{array}$ \\
\hline & & & Intradermal & NS3 & Mice & Huret et al., 2013 \\
\hline TMV CP & Plant cells & N. benthamiana & Intranasal & $\begin{array}{l}\text { E2 HVR-1 } \\
\text { mimotope R9 }\end{array}$ & Mice & Nemchinov et al., 2000 \\
\hline
\end{tabular}

TABLE 2 | Plasmid DNA and viral vectors expressing HCV virus-like particle vaccines.

\begin{tabular}{|c|c|c|c|c|c|}
\hline Vector & Viral capsid components & Route of administration & HCV antigen & Animal studies & Reference \\
\hline rVSV & HCV-core & Intravenous and intraperitoneal & Core, E1, and E2 & Mice & Majid et al., 2006 \\
\hline \multirow[t]{3}{*}{ Plasmid DNA } & HCV-core & Intradermal and intramuscular & Core, E1, and E2 & Mice & Murata et al., 2003 \\
\hline & MLV Gag & Intradermal & E1 and E2 & Mice & Desjardins et al., 2009; Huret et al., 2013 \\
\hline & & & NS3 & Mice & Huret et al., 2013 \\
\hline
\end{tabular}

TABLE 3 | Comparison of VLP expression system.

\begin{tabular}{|c|c|c|}
\hline VLP expression system & Merits & Demerits \\
\hline Bacteria & $\begin{array}{l}\text { Less expensive; simplicity of expression; fast growth rate; high-level } \\
\text { expression; genetic stability; simple process scale-up }\end{array}$ & $\begin{array}{l}\text { Lack mammalian-like PTM; Poor ability on immunogenicity; } \\
\text { Presence of host cell-derived contaminants }\end{array}$ \\
\hline Yeast & $\begin{array}{l}\text { Less expensive; high-density fermentation; modification of the } \\
\text { expression protein; moderately rapid expression; support most } \\
\text { protein folding and PTM }\end{array}$ & $\begin{array}{l}\text { High mannose modification; some secretory proteins cannot get } \\
\text { ideal results; enhanced safety precautions are required }\end{array}$ \\
\hline Insect cells & $\begin{array}{l}\text { Moderately rapid expression; support most protein folding and } \\
\text { eukaryotic-type PTM of the expression protein; works well for } \\
\text { non-enveloped and enveloped VLPs, free of mammalian pathogens }\end{array}$ & $\begin{array}{l}\text { High cost; difficult to scale-up; incomplete modification of proteins; } \\
\text { low-level expression, contamination of product with enveloped } \\
\text { baculovirus particles; perform simpler } N \text {-glycosylation compared to } \\
\text { mammalian cells }\end{array}$ \\
\hline Mammalian cells & $\begin{array}{l}\text { Perform appropriate complex mammalian-type PTMs; perform } \\
\text { authentic assembly and folding of recombinant proteins; works well } \\
\text { for non-enveloped and enveloped VLPs }\end{array}$ & $\begin{array}{l}\text { High cost; difficult to scale-up; lengthy expression time; low yield; } \\
\text { vulnerable to infection with mammalian pathogens }\end{array}$ \\
\hline Plant cells & $\begin{array}{l}\text { Rapid expression; highly scalable; less expensive; free of } \\
\text { mammalian pathogens; support most protein folding and } \\
\text { eukaryotic-type PTM }\end{array}$ & Low yield; technical and regulatory issues \\
\hline
\end{tabular}

In a heterologous prime-boost strategy, immunization with recombinant adenoviruses encoding the $\mathrm{HCV}$ structural proteins as a final booster, following priming with HCV-LPs, resulted in enhancement of both antibody and T-cell responses (Kumar et al., 2016). Additionally, the sera from immunized mice reduced the binding of VLPs and the JFH1 strain of HCV to Huh-7 cells demonstrating the presence of NAbs (Kumar et al., 2016). Even though different studies have provided evidence that HCVderived VLPs are a promising vaccine strategy, capable of eliciting $\mathrm{HCV}$-specific humoral and cellular immunity, additional studies 
are required to determine how best to induce highly protective, long-lasting immune responses.

\section{Recombinant HBV-Based VLPs Containing HCV Epitopes}

Hepatitis B virus-derived VLPs have been evaluated as carriers able to present heterologous epitopes (Chackerian, 2007), including HCV-derived antigens. In one approach, chimeric VLPs were generated by fusing target antigens to viral capsid proteins (CPs) capable of self-assembling into VLPs (Table 1). The p24/p27 protein of HBV surface antigen (HBsAg-S) has been reported to self-assemble into potent, non-infectious, secreted subviral particles and has been used in commercial vaccines against hepatitis B for over three decades. HBsAg-S particles have been designed as carriers of foreign epitopes inserted at the $\mathrm{N}$-or C-terminus or into the external hydrophilic loop of the HBsAgS (Patient et al., 2009). HCV-specific epitopes derived from the E2 protein hypervariable region 1 (HVR1) were inserted into recombinant HBsAg VLPs which were secreted from transfected mammalian cells (Netter et al., 2001; Vietheer et al., 2007). These particles were recognized by human anti-HCV-positive serum containing anti-HVR1-1b antibodies, suggesting the antigenic structure of the HVR1 region expressed on the particles' surface closely resembled the authentic structure (Netter et al., 2001). Subsequently specific antibody responses to HVR1 were efficiently induced (Netter et al., 2001; Vietheer et al., 2007). Furthermore, vaccination with a cocktail of HBsAg-S VLPs containing epitopes from either HCV-1a or -1b strains induced antibodies against both HVR1 epitopes that resulted in higher titers than those generated by immunization with the individual VLPs, suggesting a synergistic effect (Netter et al., 2001).

The insertion of the full-length HCV E1 and E2 envelope proteins into HBsAg VLPs was also shown to result in chimeric HBV-HCV particles similar in size and shape to the wild-type HBsAg subviral particles (Patient et al., 2009). Immunization of rabbits with these HBV-HCV VLPs resulted in high titers of cross-NAbs with the ability to neutralize various HCV genotypes (Beaumont et al., 2013). Recently, the immunogenicity of the chimeric HBsAg VLPs expressing E1 and E2 proteins as separate immunogens were compared with HBsAg VLPs bearing an E1E2 heterodimer (Beaumont et al., 2016). The E1- and E2- specific humoral responses induced in animals vaccinated with $\mathrm{HBsAg}$ VLPs expressing E1E2 in their heterodimer conformation, were significantly reduced compared to the responses in rabbits immunized with HBsAg VLPs expressing E1 and E2 separately (Beaumont et al., 2016). Additionally, the E1- and E2-specific antibodies showed increased cross-neutralization of various genotypes of heterologous HCV strains. These results confirmed previous observations (Garrone et al., 2011), that the E1 and E2 heterodimer is less immunogenic, possibly due to the conformational folding of E1 and E2 at the surface of the HBsAg particles contributing to the masking of certain immunodominant epitopes. Furthermore, although the folding of E1-E2 complex on the surface of the HBsAg particles was demonstrated, the structure of the E1E2 dimers on these particles might not be representative of dimers on the surface of native HCV virions. Nonetheless, these particles also generated significant levels of HBs-specific antibodies, further supporting the development of a bivalent HBV-HCV prophylactic vaccine capable of preventing primary infection with either of these two viruses (Beaumont et al., 2016). Administration of chimeric HBsAg-S/HCV VLP demonstrated that mice (Netter et al., 2003) and rabbits (Beaumont and Roingeard, 2015) with preexisting anti-HBsAg antibodies successfully generated anti-HCV antibodies, therefore these chimeric particles can be used in populations with pre-existing immunity to $\mathrm{HBV}$ as a strategy to induce protective immunity to $\mathrm{HCV}$. The encouraging results obtained so far support the development of HBV-derived VLP vaccines. However, additional studies are needed to assess the immunogenicity of these chimeric HBV/HCV particles in a larger animal model and also to develop means to further increase the broadly neutralizing characteristics of the resultant NAbs.

The HBV core protein $(\mathrm{HBc})$ naturally self assembles into dimers and subsequently into VLPs and has been used as a VLP carrier for over three decades (Clarke et al., 1987; Borisova et al., 1993). Insertion of foreign sequences into the HBc gene does not impede particle formation making $\mathrm{HBc}$ suitable for the development of a VLP vaccine displaying a foreign antigen (Ulrich et al., 1998; Sominskaya et al., 2010). Segments of HCV genes encoding the core (98 aa) or NS3 (155 aa) proteins, containing $\mathrm{B}$ - and $\mathrm{T}$-cell epitopes, were fused to the $3^{\prime}$ end of the $\mathrm{HBc}$ gene to generate chimeric $\mathrm{HBc} / \mathrm{HCV}$ VLPs (Mihailova et al., 2006). These two proteins were chosen as immunogens because the induction of broad CD4+ and CD8+ T-cell responses to various HCV proteins, including core and NS3 is typically associated with resolution and control of HCV infection (Neumann-Haefelin et al., 2005). Administration of the $\mathrm{HBc} / \mathrm{HCV}$ core particles induced moderately low antibody levels and proliferative responses of T-cell to HCV core epitopes, while vaccination with the $\mathrm{HBc} / \mathrm{HCV}$ NS3 particles induced significant levels of anti-NS3 antibodies with no proliferative responses to HCV epitopes (Mihailova et al., 2006). However, antibodies to core and NS3 are believed to have no prophylactic value and are generally not considered to be protective in natural HCV infection. Furthermore, variations in the immune responses to the chimeric particles might be caused by alternative presentation of inserted HCV sequences in the context of the chimeric particles (Mihailova et al., 2006). Similarly, chimeric VLPs carrying a virus-neutralizing HBV pre-S1 epitope and a highly conserved $\mathrm{N}$-terminal $\mathrm{HCV}$ core epitope at the $\mathrm{C}$ terminus of the truncated $\mathrm{HBc}$ protein (HBc-pre-S1-HCVcore) have been successfully generated (Sominskaya et al., 2010). Vaccination with these particles induced high $\mathrm{T}$ cell immunity similar to that induced by the monovalent $\mathrm{HBc}-\mathrm{HCV}$ core particles, but induced low antibody responses to HCV core epitopes. It was argued that the core epitopes located at the $\mathrm{C}$ terminus were not exposed on the surface of the VLP and therefore were not able to induce strong antibody responses (Sominskaya et al., 2010). This further highlights the importance of the position of inserted epitopes within $\mathrm{HBc}$ in terms of the particle's humoral immunogenicity. Insertion of larger amino acid sequences would be beneficial for the development and production of a multivalent $\mathrm{HCV}$ vaccine carrying a larger number of epitopes coupled to one 
carrier molecule and facilitate proper folding of conformational epitopes which is important for the generation of NAbs. However, inserting larger inserts within the $\mathrm{HBc}$ particles might affect the ability of the chimeric particles to drive insert-specific immune responses. Various studies have reported contradictory results regarding the maximum insertion capacity of $\mathrm{HBc}$ without affecting immunogenicity to the insert antigen and HBc's ability to successfully form particles. A maximum of 90 aa of human immunodeficiency virus (Kalams et al., 2013). Gag protein was reported to be tolerated while fusion of 317,189 , or 100 aa of the Gag protein downstream of aa 144 prevented self-assembly of the chimeric HBc particles (Ulrich et al., 1992). Yoshikawa et al. (1993), on the other hand, reported successful formation of HBc particles carrying a 720 aa segment composed of four copies of an 180 aa sequence derived from HCV core protein. However, the immunogenicity of these particles was not assessed in an in vivo model.

\section{Recombinant Retrovirus-Based HCV VLPs}

Complete glycoproteins can also be displayed in their native conformation on the surface of retroviral particles by a process known as pseudotyping. Infectious HCVpp which are engineered by pseudotyping HCV glycoproteins onto murine leukemia virus (MLV)-Gag retroviral core particles have been used to comprehensively study the early events of $\mathrm{HCV}$ infection, as well as the role of putative $\mathrm{HCV}$ receptors (Bartosch et al., 2003b). These particles are also commonly used to detect and measure anti-HCV NAb in HCV patients (Bartosch et al., 2003a; Drummer et al., 2003). HCV-pseudotyped retrovirus-derived VLPs devoid of a genome (HCV-retro VLPs) have been proposed as a vaccine platform. Studies of the molecular structure of these pseudoparticles described HCVpp and HCV-retro VLPs as regular $100 \mathrm{~nm}$ spherical structures comprised of the dense retroviral nucleocapsid surrounded by a lipid bilayer (Bonnafous et al., 2010; Garrone et al., 2011). Following priming with HCV-recombinant viral vectors, VLPs pseudotyped with E2 and/or E1 HCV glycoproteins generated significant anti-E2 and/or anti-E1 antibody titers in mice and macaques (Garrone et al., 2011). This highlighted the difficulty of inducing an anti-E1 antibody response, consistent with the findings that these antibodies are generally detected at low levels in patients (Leroux-Roels et al., 1996; Pestka et al., 2007). Of the regimens examined, only the VLPs induced significant levels of anti-E1 antibodies, which were generated provided that E1 was dissociated from E2. More importantly, boosting with the retrovirus-derived VLPs in a heterologous prime-boost combination with plasmo-retroVLP raised NAbs against HCV genotype 1a which cross-neutralized five other genotypes/strains (1b, 2a, 2b, 4, and 5) (Huret et al., 2013). No challenge experiments were conducted to assess the anti-HCV potency of these HCV-retro VLPs. Overall, retrovirus-derived VLPs pseudotyped with an assortment of virus envelopes, represent a versatile and efficient platform for vaccination not only against $\mathrm{HCV}$ but also against major infectious diseases such HIV/AIDS, yellow fever and dengue fever. However, despite these encouraging results, the use of animal retroviral particles has not been validated as a safe or effective preventative vaccine in humans, and scaling up the manufacturing process may present a limiting factor for the development of recombinant retrovirus-based HCV VLP vaccines.

\section{Recombinant Vesicular Stomatitis Virus Vectors Expressing HCV VLPs}

Recombinant vesicular stomatitis virus (rVSV) has been shown to be an effective expression vector in a number of different vaccine strategies (Table 2) (Schnell et al., 1996; Kretzschmar et al., 1997). There are several advantages of using rVSV encoding foreign viral proteins as a vaccine candidate. The virus has a low seroprevalence in the community and is not pathogenic in humans; the simple genome has only five genes $(\mathrm{N}, \mathrm{P}, \mathrm{M}, \mathrm{G}$, and $\mathrm{L})$ and it does not undergo reassortment or integration (Johnson et al., 1966; Fields and Hawkins, 1967; Ezelle et al., 2002). Recombinant VSV has been evaluated as a candidate for $\mathrm{HCV}$ vaccination by encoding $\mathrm{HCV}$ core, E1 and E2 proteins (rVSV-C/E1/E2) which can self-assemble into HCV VLPs (VSV-HCV-VLPs) in baby hamster kidney fibroblasts (BHK-21 cells) (Ezelle et al., 2002). These VSV-HCV-VLPs showed similar ultrastructural properties to HCV virions (Ezelle et al., 2002). Vaccination with these particles induced core-, E1- and E2-specific cell mediated responses as well as anti-E2 antibody responses (Ezelle et al., 2002). However, it was argued that these particles may represent the endogenous viruses of BHK-21 cells known as intracisternal R-type particles, rather than the complete budded HCV-like particles (Blanchard et al., 2003). Subsequently it was demonstrated that the expression of HCV E1 and E2 by replication-competent and-defective (G-protein-deleted) VSV vectors resulted in correctly folded E1/E2 heterodimers (Majid et al., 2006). Nevertheless, this study only assessed the expression of the envelope proteins but did not provide a detailed characterization of the formed VSV-HCV-VLPs. Immunization with rVSV $\Delta \mathrm{G}-\mathrm{C} / \mathrm{E} 1 / \mathrm{E} 2$ resulted in significant $\mathrm{T}$ cell responses to core, $\mathrm{E} 1$ and $\mathrm{E} 2$, along with anti-core and anti-E2 antibody responses (Ezelle et al., 2002; Majid et al., 2006). Neutralizing antibody responses were not assessed. However, immunization with $\mathrm{rVSV} \Delta \mathrm{G}-\mathrm{C} / \mathrm{E} 1 / \mathrm{E} 2$ protected mice against the formation of tumors expressing $\mathrm{HCV}$ E2 (CT26-hghE2t) and showed CT26-hghE2t-specific as well as E2-specific T-cell responses. Recombinant VSV expressing $\mathrm{HCV}$ structural proteins represent a versatile tool in vaccine development, which cannot only be used as a vector for the production of HCV VLPs in mammalian cells but also as a vaccine candidate itself. The recent effectiveness of an Ebola vaccine candidate rVSV-ZEBOV (Regules et al., 2017), comprising a live-attenuated VSV encoding the Ebola virus glycoprotein, in preventing Ebola virus disease in recently diagnosed patients, their contacts and contacts' contacts (ElSherif et al., 2017; Halperin et al., 2017; Henao-Restrepo et al., 2017) provides hope for the development of a VLP-based $\mathrm{HCV}$ vaccine using this strategy. However, further studies are required to better characterize and improve the production VSV-HCV-VLPs. The protective immunity generated by rVSVs encoding $\mathrm{HCV}$ core, E1 and E2 also needs to be evaluated 
before these particles can be used as a vaccine against $\mathrm{HCV}$ infection.

\section{DNA Vaccines Encoding Recombinant Retrovirus-Based HCV VLPs}

DNA plasmids generating recombinant retro-VLPs (plasmoretroVLPs) (Bellier et al., 2006, 2009; Desjardins et al., 2009) represent a HCV genetic vaccine circumventing the in vitro production and purification of retro-VLPs. These plasmoretroVLPs have been engineered to produce in situ retroVLPs pseudotyped with E1 and E2 proteins after in vivo delivery of the DNA (Table 2). By doing so, this strategy combines the benefits of DNA vaccines such as the ease of development, low-cost largescale production and stability with the immuno-stimulatory properties of VLPs, while circumventing the in vitro production of VLP vaccines. It has been shown that administration of plasmo-retroVLPs result in the induction of significantly higher antigen-specific responses and antiviral immune protection than plasmids that were mutated to prevent plasmo-retroVLP assembly (Bellier et al., 2006, 2009). It was also shown in heterologous prime-boost immunization strategies, that HCVplasmo-retroVLPs were superior immunogens for boosting cellular and humoral immune responses in primed animals than plasmids unable to form E1/E2-pseudotyped retroVLPs (Bellier et al., 2009; Desjardins et al., 2009). A combination of two plasmo-retroVLPs vaccinations followed by a boost with ex vivo produced VLPs was shown to induce HCVspecific cell-mediated response and NAbs (Huret et al., 2013). Furthermore, vaccination with a cocktail of plasmo-retroVLPs pseudotyped with E1E2 from HCV genotypes 1a, 1b, 2b, 3a, $4 c$, and 5, and/or displaying NS3 antigen in CPs resulted in immune responses against the five $\mathrm{HCV}$ genotypes (Huret et al., 2013). A major advantage of plasmo-retroVLPs is that they can be re-administered for sequential vaccinations without the concern of pre-existing vector- associated immunity (Bellier et al., 2009). DNA-based vaccines, however, generally induce relatively weak immune responses to antigens and are therefore regarded as inferior compared to traditional vaccines such as subunit vaccines. As such, even the above strategy required boost immunizations with purified VLPs for maximum activity. The delivery route and/or method of DNA-based vaccines is also a critical factor in determining vaccination outcome. VSV-G specific plasmo-retroVLPs have been shown to induce higher levels of VSV-G-specific humoral and cell mediated immune responses following administration by needlefree intradermal (i.d.) injection compared to immunization with a gene gun (Bellier et al., 2009). Additionally, needlefree i.d. co-injection of cytokine genes or $\mathrm{CpG}$ sequences significantly increased VSV-G-specific NAbs levels (Bellier et al., 2009). Therefore, attempts should be directed toward the optimization of the delivery methods of DNA-based VLP vaccines and the addition or co-delivery of novel genetic adjuvants for maximum immune stimulation. Together, these results show that the plasmo-retroVLPs is a flexible platform to induce humoral and cellular immunity after homologous or heterologous prime-boost immunization and with further improvements, this strategy could be used as a promising approach to generate enhanced immune responses against $\mathrm{HCV}$.

\section{Recombinant Papaya Mosaic Virus-Based HCV VLPs}

Virus like particles derived from plant viruses have also emerged as a promising strategy for the development of viral vaccines. The papaya mosaic virus (PapMV) CP has triggered much interest as an epitope presentation system. Several hundred units of the PapMV CP have been reported to assemble in an organized and repetitive manner into particles ranging from 60 to $100 \mathrm{~nm}$ in length following expression in Escherichia coli (Tremblay et al., 2006). A recombinant multimeric PapMV vaccine platform expressing a HCV-E2 peptide fused to the C-terminal PapMV CP was shown to trigger a strong humoral immune response in mice lasting more than 120 days against the $\mathrm{CP}$ and the E2 epitope (Table 1) (Denis et al., 2007). Notably, the same platform was less effective when inoculated as a monomeric protein, confirming the observation that immunogenicity is strongly dependent on the repetitive organization of the antigen (Denis et al., 2007). This VLP platform faces challenges which might limit its clinical development as vaccine, including the presence of bacterial RNA used a scaffold for PapMV CP self-assembly (Tremblay et al., 2006), as well as the possibility that antigen fusion might alter the antigen conformation or interfere with the protein assembly and VLP formation.

\section{HCV VLP PRODUCTION SYSTEMS}

Many expression systems for the production of VLPs are currently in use, including various species of yeast such as Saccharomyces cerevisiae (S. cerevisiae) and Pichia pastoris (P. pastoris), bacteria (mainly E. coli), the baculovirus expression vector/insect cell system (BEVS/IC), and various mammalian cell lines, as well as various plants (tobacco, lettuce leaves) (Table 3 ). The production system used depends on the need to retain more consistent original VLP formation and post translational modifications (PTMs, e.g., glycosylation and phosphorylation) while significantly reducing production times and costs. All production systems have advantages and drawbacks as discussed briefly.

\section{Bacteria and Yeast}

Bacterial systems are the most commonly used system to manufacture recombinant proteins and have been used to produce non-enveloped HCV VLPs. E. coli-derived HCV core proteins self-assembled in vitro into particles of approximately $60 \mathrm{~nm}$ in diameter (Kunkel et al., 2001). Lorenzo et al. (2001) on the other hand, produced VLPs in E. coli following expression of truncated HCV core protein consisting of the first 120 amino acids. Similarly, the recombinant HCV-E2 PapMV CP VLPs were also produced following expression in E. coli (Denis et al., 2007; Rioux et al., 2012). However, several factors including the lack of a mammalian-like PTM system means that this platform is not preferred for VLP production (Table 3). Additionally, the downstream processing of the VLPs is compromised by 
the presence host cell derived toxins, heat shock proteins or chaperone proteins, increasing the final production cost (Zhang et al., 1998; Lai and Middelberg, 2002).

Yeast is another well-established platform used for recombinant protein expression and VLP production. Four licensed VLP-based vaccines, Engerix-B ${ }^{\circledR}$, HepavaxGene $^{\circledR}$, Recombivax $\mathrm{HB}^{\circledR}$ and Gardasil ${ }^{\circledR}$ (Merck and Co), are manufactured using this system. The entire HCV core protein expressed in methylotrophic $P$. pastoris formed particles with similar structural properties as the native mature $\mathrm{HCV}$ nucleocapsid particles, and were successfully recognized by serum from a persistently infected HCV patient (Acosta-Rivero et al., 2001, 2004). More recently, VLPs of $70 \mathrm{~nm}$ in diameter were generated following expression of recombinant $\mathrm{HCV}$ coreE1E2 proteins in $P$. pastoris and were able to efficiently induce anti-CoreE1E2 antibodies in rabbits (Fazlalipour et al., 2015). However, concerns about appropriate protein processing, protein folding, and post translational modification, may direct the choice toward an alternative production system (Acosta-Rivero et al., 2004; Kushnir et al., 2012).

\section{Mammalian Cells}

Mammalian cell expression systems are favored because they are capable of performing appropriate complex mammalian-type PTMs and authentic assembly of recombinant proteins (Chua et al., 2012; Earnest-Silveira et al., 2016b; Kumar et al., 2016). Various HCV VLPs vaccine candidates have been successfully produced in mammalian cells including Chinese hamster ovary (CHO), Huh-7cells, and human embryonic kidney (HEK) 293T cells (Table 1). Immunization with recombinant HCV envelope glycoproteins produced in mammalian cells protected chimpanzees more effectively compared to those produced in yeast or insect cells after challenge with a homologous HCV isolate (Choo et al., 1994). Similarly, mammalian cellderived recombinant envelope proteins have been reported to bind strongly to human cells compared to those produced in yeast or insect cells (Rosa et al., 1996). More recently VLPs produced in mammalian cells were found to be more immunogenic in a VLP prime/Rec-Ad-C-E1-E2 boost based heterologous strategy, when compared to VLPs produced using the baculovirus-insect cell system (Kumar et al., 2016). To avoid the deleterious effects of cesium chloride $(\mathrm{CsCl})$, the use of iodixanol ultracentrifugation and stirred cell ultrafiltration resulted in the production of large quantities of HCV VLPs from various genotypes as a strategy for the manufacture of a quadrivalent mammalian cell derived HCV VLP vaccine (Earnest-Silveira et al., 2016a,b).

\section{Plant Cells}

Plant production platforms have many advantages compared to mammalian cells (Table 3). Plant-derived VLPs offer a new approach for oral delivery of vaccines. Plant expression systems are highly scalable, economical and free of mammalian pathogens. Additionally, plant production systems possess eukaryotic-like protein folding and PTMs similar to mammalian cells (Mett et al., 2008; Yusibov and Rabindran, 2008; Kushnir et al., 2012). Plant expression systems are suitable for the production of both non-enveloped and enveloped VLPs (D'Aoust et al., 2008; Santi et al., 2008). A tobacco mosaic virus (TMV)-derived vector encoding a HVRlpeptide (containing a HCV neutralizing epitope) fused to the C-terminus of the $B$ subunit of cholera toxin (CTB) was used to infect tobacco plants (Nicotiana benthamiana) (Nemchinov et al., 2000; Rybicki, 2014). Infected plants successfully generated TMV particles expressing HVR1/CTB (Nemchinov et al., 2000). The plant-derived HVR1/CTB reacted with anti-HRV1 monoclonal antibodies and sera from $\mathrm{HCV}$-positive individuals infected with four of the major genotypes of HCV. Inoculating mice with plant extract resulted in the induction of both anti-CTB and anti-HVR1 antibodies capable of specifically binding to HCV VLPs (Nemchinov et al., 2000). A plant-derived HCV vaccine can reduce manufacturing costs associated with the production of conventional vaccines and the vaccine can be administered in edible plant part this would particularly helpful in reducing incidence of $\mathrm{HCV}$ in the developing world. However, to date no plant-derived VLPs have been licensed for human use. In addition, the dosage required for effective vaccination might vary depending on the plants used, ripeness of the fruit and the quantity of food consumed. Therefore, administration of edible vaccines requires to be standardized to evaluate the dosage requirement for effective vaccination. Also, certain plants and fruits are generally not eaten raw and cooking would result in denaturation of the protein and a reduction in immunogenicity to the vaccine. Most plants and fruits are susceptible to microbial infestation and this would affect the stability of the vaccine.

\section{Insect Cells}

The baculovirus-insect cell expression system has also been widely used for VLP production (van Oers et al., 2015). Insect cells have been employed to express several VLP-based vaccines, notably one of the current HPV vaccines, Cervarix ${ }^{\circledR}$. The baculovirus-insect cell system can be used to manufacture nonenveloped and enveloped VLPs (Table 3 ) and various HCV VLPs have been successfully produced using this system (Table 1) (Baumert et al., 1999; Wellnitz et al., 2002; Choi et al., 2004; Zhao et al., 2004). The insect cell system can perform eukaryotictype PTMs, support high expression levels of foreign proteins with the advantage of lacking mammalian pathogens (Roy and Noad, 2008; Kushnir et al., 2012). Expression of core, E1 and E2 proteins in the recombinant baculovirus system resulted in the formation of recombinant virus particles (Baumert et al., 1998, 1999, 2000) capable of inducing antibodies and cell-mediated immune responses after immunization in rabbits. A major disadvantage of this system is contamination of the product with co-produced enveloped baculovirus particles (Buonaguro et al., 2006; Palomares and Ramirez, 2009), which require the development of more complex and stringent VLP purification systems. Another limitation of this system is that insect cells perform simpler $N$-glycosylation compared to mammalian cells, which is troublesome in vaccine developments as correct glycosylation is often necessary for optimum immunogenicity of the vaccine antigen (Kost et al., 2005; Orlova et al., 2015). 


\section{DOWNSTREAM PROCESSING OF VLP VACCINES}

The purity, potency and consistency of the particles and elimination of host cell and culture media contaminants are crucial for the downstream processing of VLP-based vaccines. In addition, the purification methods should be robust, costeffective, scalable and preferably applicable to a wide variety of VLPs.

Virus like particles are purified using methods originally developed for the purification of viruses by which particles are purified based on their size and density using ultracentrifugation through sucrose or $\mathrm{CsCl}$ gradients (Vicente et al., 2011). However, ultracentrifugation-based methods are not practical for large scale vaccine development as they are non-scalable, tedious and highly labor intensive. Furthermore, use of $\mathrm{CsCl}$ is problematic due to its toxicity, reduced infectivity of viruses and particle deformation (Burova and Ioffe, 2005). Due to these limitations, there is currently a trend moving away from traditional VLP purification methods toward more scalable sophisticated techniques such as chromatography (Morenweiser, 2005; Vicente et al., 2011). Here, crude lysate is initially clarified by low-speed centrifugation or tangential flow filtration prior to chromatography (ion exchange, affinity, or sizeexclusion). Chromatography provides a convenient and practical intermediate step for capturing and concentrating VLPs from cellular and media contaminants (Morenweiser, 2005).

\section{CONCLUSION}

The path to a HCV vaccine has been fraught with difficulties mainly because of the virulent nature of the virus and its ability to evade the immune responses due to its heterogeneity. However, advances in technology and our understanding of the natural course of HCV infection, the pathogenetic mechanisms, and the immunological markers which correlate with resolution of infection or protection, provide useful information for vaccine design. VLP vaccines have many favorable immunological characteristics making them promising $\mathrm{HCV}$ vaccine candidates. Currently, no VLP-based HCV vaccines have progressed to

\section{REFERENCES}

Acosta-Rivero, N., Aguilar, J. C., Musacchio, A., Falcón, V., Viña, A., de la Rosa, M. C., et al. (2001). Characterization of the HCV core virus-like particles produced in the methylotrophic yeast Pichia pastoris. Biochem. Biophys. Res. Commun. 287, 122-125. doi: 10.1006/bbrc.2001.5561

Acosta-Rivero, N., Rodriguez, A., Musacchio, A., Falcón, V., Suarez, V. M., Martinez, G., et al. (2004). In vitro assembly into virus-like particles is an intrinsic quality of Pichia pastoris derived HCV core protein. Biochem. Biophys. Res. Commun. 325, 68-74. doi: 10.1016/j.bbrc.2004.10.012

Ahlén, G., Frelin, L., Brenndörfer, E. D., Brass, A., Weiland, O., Chen, M., et al. (2013). Containing “The Great Houdini” of viruses: combining direct acting antivirals with the host immune response for the treatment of chronic hepatitis C. Drug Resist. Updat. 16, 60-67. doi: 10.1016/j.drup.2013.06.001

Akahata, W., Yang, Z. Y., Andersen, H., Sun, S., Holdaway, H. A., Kong, W. P., et al. (2010). A virus-like particle vaccine for epidemic Chikungunya human clinical trials. However, VLP-based vaccines for the prevention of HBV and HPV infections have already been licensed, supporting the development of VLP-based vaccines for HCV. The HCV VLP-based vaccine candidates that have been developed so far have generated promising data in preclinical animal studies. It is widely known that several factors, including the expression system, will affect the quality and production yields of viral particles. Several expression systems have been effectively used to produce VLP vaccine candidate. Some VLP-based HCV vaccine candidates such as chimeric $\mathrm{HBV} / \mathrm{HCV}$ VLPs can be produced using already established production systems such as bacterial and yeast. However, these particles can be contaminated with residual host cell factors such as lipids, nucleic acids and proteins that may stimulate innate immune responses and/or reduce the specific adaptive immune response and therefore may have a significant impact on VLP-based vaccine development that could present a bottleneck in their development. VLPs produced using mammalian cells offer an alternative system which supports appropriate complex mammalian-type PTMs and performs authentic assembly and folding of recombinant proteins and therefore generates VLPs that are very similar to the authentic HCV virion. However, difficulties in scaling up this system and high-production costs might direct the choice toward more cost effective alternative production system. Genetic vaccines that express HCV-recombinant VLPs, on the other hand are attractive candidates as the production of high quality plasmid DNA is simple and inexpensive to scale-up and could further advance the development of novel VLP-based strategies. Ultimately, it is hoped that newly developed VLPs can elicit specific and strong responses to HCV to prevent and contain infection. These encouraging results from pre-clinical animal studies suggest that it should be possible to develop such a vaccine although this may yet be some way off.

\section{AUTHOR CONTRIBUTIONS}

MM conceived the initial draft of the manuscript. DW, JT, EG, and $B G-B$ revised many parts of the manuscript, and contributed to finalize the manuscript.

virus protects nonhuman primates against infection. Nat. Med. 16, 334-338. doi: $10.1038 / \mathrm{nm} .2105$

Bartenschlager, R., Penin, F., Lohmann, V., and André, P. (2011). Assembly of infectious hepatitis C virus particles. Trends Microbiol. 19, 95-103. doi: 10.1016/ j.tim.2010.11.005

Barth, H., Ulsenheimer, A., Pape, G. R., Diepolder, H. M., Hoffmann, M., Neumann-Haefelin, C., et al. (2005). Uptake and presentation of hepatitis C virus-like particles by human dendritic cells. Blood 105, 3605-3614. doi: 10.1182/blood-2004-05-1952

Bartosch, B., Bukh, J., Meunier, J. C., Granier, C., Engle, R. E., Blackwelder, W. C., et al. (2003a). In vitro assay for neutralizing antibody to hepatitis $C$ virus: evidence for broadly conserved neutralization epitopes. Proc. Natl. Acad. Sci. U.S.A. 100, 14199-14204. doi: 10.1073/pnas.2335981100

Bartosch, B., Dubuisson, J., and Cosset, F. L. (2003b). Infectious hepatitis C virus pseudo-particles containing functional E1-E2 envelope protein complexes. J. Exp. Med. 197, 633-642. doi: 10.1084/jem.20021756 
Baumert, T. F., Ito, S., Wong, D. T., and Liang, T. J. (1998). Hepatitis C virus structural proteins assemble into viruslike particles in insect cells. J. Virol. 72, 3827-3836.

Baumert, T. F., Vergalla, J., Satoi, J., Thomson, M., Lechmann, M., Herion, D., et al. (1999). Hepatitis C virus-like particles synthesized in insect cells as a potential vaccine candidate. Gastroenterology 117, 1397-1407. doi: 10.1016/ S0016-5085(99)70290-8

Baumert, T. F., Wellnitz, S., Aono, S., Satoi, J., Herion, D., Tilman Gerlach, J., et al. (2000). Antibodies against hepatitis $C$ virus-like particles and viral clearance in acute and chronic hepatitis C. Hepatology 32, 610-617. doi: 10.1053/jhep.2000. 9876

Beaumont, E., Patient, R., Hourioux, C., Dimier-Poisson, I., and Roingeard, P. (2013). Chimeric hepatitis B virus/hepatitis C virus envelope proteins elicit broadly neutralizing antibodies and constitute a potential bivalent prophylactic vaccine. Hepatology 57, 1303-1313. doi: 10.1002/hep.26132

Beaumont, E., Roch, E., Chopin, L., and Roingeard, P. (2016). Hepatitis C virus E1 and E2 proteins used as separate immunogens induce neutralizing antibodies with additive properties. PLOS ONE 11:e0151626. doi: 10.1371/journal.pone. 0151626

Beaumont, E., and Roingeard, P. (2015). Chimeric hepatitis B virus (HBV)/hepatitis C virus (HCV) subviral envelope particles induce efficient anti-HCV antibody production in animals pre-immunized with $\mathrm{HBV}$ vaccine. Vaccine 33, 973-976. doi: 10.1016/j.vaccine.2015.01.007

Bellier, B., Dalba, C., Clerc, B., Desjardins, D., Drury, R., Cosset, F. L., et al. (2006). DNA vaccines encoding retrovirus-based virus-like particles induce efficient immune responses without adjuvant. Vaccine 24, 2643-2655. doi: 10.1016/j. vaccine.2005.11.034

Bellier, B., Huret, C., Miyalou, M., Desjardins, D., Frenkiel, M. P., Despres, P., et al. (2009). DNA vaccines expressing retrovirus-like particles are efficient immunogens to induce neutralizing antibodies. Vaccine 27, 5772-5780. doi: 10.1016/j.vaccine.2009.07.059

Bellier, B., and Klatzmann, D. (2013). Virus-like particle-based vaccines against hepatitis C virus infection. Expert Rev. Vaccines 12, 143-154. doi: 10.1586/erv. 13.10

Blanchard, E., Brand, D., and Roingeard, P. (2003). Endogenous virus and hepatitis $\mathrm{C}$ virus-like particle budding in BHK-21 cells. J. Virol. 77, 3888-3889. doi: 10.1128/JVI.77.6.3888-3889.2003

Bonnafous, P., Perrault, M., Le Bihan, O., Bartosch, B., Lavillette, D., Penin, F., et al. (2010). Characterization of hepatitis C virus pseudoparticles by cryotransmission electron microscopy using functionalized magnetic nanobeads. J. Gen. Virol. 91(Pt 8), 1919-1930. doi: 10.1099/vir.0.021071-0

Borisova, G., Arya, B., Dislers, A., Borschukova, O., Tsibinogin, V., Skrastina, D., et al. (1993). Hybrid hepatitis B virus nucleocapsid bearing an immunodominant region from hepatitis B virus surface antigen. J. Virol. 67, 3696-3701.

Bukh, J., Thimme, R., Meunier, J. C., Faulk, K., Spangenberg, H. C., Chang, K. M., et al. (2008). Previously infected chimpanzees are not consistently protected against reinfection or persistent infection after reexposure to the identical hepatitis C virus strain. J. Virol. 82, 8183-8195. doi: 10.1128/JVI.00142-08

Buonaguro, L., Tornesello, M. L., Tagliamonte, M., Gallo, R. C., Wang, L. X., Kamin-Lewis, R., et al. (2006). Baculovirus-derived human immunodeficiency virus type 1 virus-like particles activate dendritic cells and induce ex vivo T-cell responses. J. Virol. 80, 9134-9143. doi: 10.1128/JVI.00050-06

Burova, E., and Ioffe, E. (2005). Chromatographic purification of recombinant adenoviral and adeno-associated viral vectors: methods and implications. Gene Ther. 12(Suppl. 1), S5-S17. doi: 10.1038/sj.gt.3302611

Chackerian, B. (2007). Virus-like particles: flexible platforms for vaccine development. Expert Rev. Vaccines 6, 381-390. doi: 10.1586/14760584.6.3.381

Choi, S. H., Kim, S. Y., Park, K. J., Kim, Y. J., and Hwang, S. B. (2004). Hepatitis C virus core protein is efficiently released into the culture medium in insect cells. J. Biochem. Mol. Biol. 37, 735-740. doi: 10.5483/BMBRep.2004.37.6.735

Choo, Q. L., Kuo, G., Ralston, R., Weiner, A., Chien, D., Van Nest, G., et al. (1994). Vaccination of chimpanzees against infection by the hepatitis C virus. Proc. Natl. Acad. Sci. U.S.A. 91, 1294-1298. doi: 10.1073/pnas.91.4.1294

Chua, B. Y., Johnson, D., Tan, A., Earnest-Silveira, L., Sekiya, T., Chin, R., et al. (2012). Hepatitis C VLPs delivered to dendritic cells by a TLR2 targeting lipopeptide results in enhanced antibody and cell-mediated responses. PLOS ONE 7:e47492. doi: 10.1371/journal.pone.0047492
Clarke, B. E., Newton, S. E., Carroll, A. R., Francis, M. J., Appleyard, G., Syred, A. D., et al. (1987). Improved immunogenicity of a peptide epitope after fusion to hepatitis B core protein. Nature 330, 381-384. doi: 10.1038/330 $381 \mathrm{a} 0$

Commonwealth of Australia (2014). Fourth National Hepatitis Strategy 2014-2017. Canberra, ACT: Commonwealth of Australia.

D’Aoust, M. A., Lavoie, P. O., Couture, M. M., Trépanier, S., Guay, J. M., Dargis, M., et al. (2008). Influenza virus-like particles produced by transient expression in Nicotiana benthamiana induce a protective immune response against a lethal viral challenge in mice. Plant Biotechnol. J. 6, 930-940. doi: 10.1111/j.14677652.2008.00384.x

Denis, J., Majeau, N., Acosta-Ramirez, E., Savard, C., Bedard, M. C., Simard, S., et al. (2007). Immunogenicity of papaya mosaic virus-like particles fused to a hepatitis $\mathrm{C}$ virus epitope: evidence for the critical function of multimerization. Virology 363, 59-68. doi: 10.1016/j.virol.2007.01.011

Desjardins, D., Huret, C., Dalba, C., Kreppel, F., Kochanek, S., Cosset, F. L., et al. (2009). Recombinant retrovirus-like particle forming DNA vaccines in primeboost immunization and their use for hepatitis $\mathrm{C}$ virus vaccine development. J. Gene Med. 11, 313-325. doi: 10.1002/jgm.1307

Drummer, H. E., Maerz, A., and Poumbourios, P. (2003). Cell surface expression of functional hepatitis C virus E1 and E2 glycoproteins. FEBS Lett. 546, 385-390. doi: 10.1016/S0014-5793(03)00635-5

Earnest-Silveira, L., Christiansen, D., Herrmann, S., Ralph, S. A., Das, S., Gowans, E. J., et al. (2016a). Large scale production of a mammalian cell derived quadrivalent hepatitis C virus like particle vaccine. J. Virol. Methods 236, 87-92. doi: 10.1016/j.jviromet.2016.06.012

Earnest-Silveira, L., Chua, B., Chin, R., Christiansen, D., Johnson, D., Herrmann, S., et al. (2016b). Characterization of a hepatitis C virus like particle vaccine produced in a human hepatocyte-derived cell line. J. Gen. Virol. 97, 1865-1876. doi: 10.1099/jgv.0.000493

Elmowalid, G. A., Qiao, M., Jeong, S. H., Borg, B. B., Baumert, T. F., Sapp, R. K., et al. (2007). Immunization with hepatitis C virus-like particles results in control of hepatitis $\mathrm{C}$ virus infection in chimpanzees. Proc. Natl. Acad. Sci. U.S.A. 104, 8427-8432. doi: 10.1073/pnas.0702162104

ElSherif, M. S., Brown, C., MacKinnon-Cameron, D., Li, L., Racine, T., Alimonti, J., et al. (2017). Assessing the safety and immunogenicity of recombinant vesicular stomatitis virus Ebola vaccine in healthy adults: a randomized clinical trial. CMAJ 189, E819-E827. doi: 10.1503/cmaj.170074

Ezelle, H. J., Markovic, D., and Barber, G. N. (2002). Generation of hepatitis C virus-like particles by use of a recombinant vesicular stomatitis virus vector. J. Virol. 76, 12325-12334. doi: 10.1128/JVI.76.23.12325-12334.2002

Farci, P., Alter, H. J., Govindarajan, S., Wong, D. C., Engle, R., Lesniewski, R. R., et al. (1992). Lack of protective immunity against reinfection with hepatitis C virus. Science 258, 135-140. doi: 10.1126/science.1279801

Farci, P., Shimoda, A., Wong, D., Cabezon, T., De Gioannis, D., Strazzera, A., et al. (1996). Prevention of hepatitis C virus infection in chimpanzees by hyperimmune serum against the hypervariable region 1 of the envelope 2 protein. Proc. Natl. Acad. Sci. U.S.A. 93, 15394-15399. doi: 10.1073/pnas.93.26. 15394

Fazlalipour, M., Keyvani, H., Monavari, S. H., and Mollaie, H. R. (2015). Expression, purification and immunogenic description of a hepatitis $\mathrm{C}$ virus recombinant CoreE1E2 protein expressed by yeast Pichia pastoris. Jundishapur J. Microbiol. 8:e17157. doi: 10.5812/jjm.8(4)2015.17157

Fields, B. N., and Hawkins, K. (1967). Human infection with the virus of vesicular stomatitis during an epizootic. N. Engl. J. Med. 277, 989-994. doi: 10.1056/ NEJM196711092771901

Forns, X., Bukh, J., and Purcell, R. H. (2002). The challenge of developing a vaccine against hepatitis C virus. J. Hepatol. 37, 684-695. doi: 10.1016/S0168-8278(02) 00308-2

Forns, X., Payette, P. J., Ma, X., Satterfield, W., Eder, G., Mushahwar, I. K., et al. (2000). Vaccination of chimpanzees with plasmid DNA encoding the hepatitis $\mathrm{C}$ virus (HCV) envelope E2 protein modified the infection after challenge with homologous monoclonal HCV. Hepatology 32, 618-625. doi: 10.1053/jhep. 2000.9877

Garrone, P., Fluckiger, A. C., Mangeot, P. E., Gauthier, E., Dupeyrot-Lacas, P., Mancip, J., et al. (2011). A prime-boost strategy using virus-like particles pseudotyped for HCV proteins triggers broadly neutralizing antibodies in macaques. Sci. Transl. Med. 3:94ra71. doi: 10.1126/scitranslmed.3002330 
Gower, E., Estes, C., Blach, S., Razavi-Shearer, K., and Razavi, H. (2014). Global epidemiology and genotype distribution of the hepatitis $\mathrm{C}$ virus infection. J. Hepatol. 61(1 Suppl.), S45-S57. doi: 10.1016/j.jhep.2014.07.027

Halliday, J., Klenerman, P., and Barnes, E. (2011). Vaccination for hepatitis C virus: closing in on an evasive target. Expert Rev. Vaccines. 10, 659-672. doi: 10.1586/erv.11.55

Halperin, S. A., Arribas, J. R., Rupp, R., Andrews, C. P., Chu, L., Das, R., et al. (2017). Six-month safety data of recombinant vesicular stomatitis Virus-Zaire Ebola Virus envelope glycoprotein vaccine in a phase 3 double-blind, placebocontrolled randomized study in healthy adults. J. Infect. Dis. 215, 1789-1798. doi: 10.1093/infdis/jix189

Henao-Restrepo, A. M., Camacho, A., Longini, I. M., Watson, C. H., Edmunds, W. J., Egger, M., et al. (2017). Efficacy and effectiveness of an rVSV-vectored vaccine in preventing Ebola virus disease: final results from the Guinea ring vaccination, open-label, cluster-randomised trial (Ebola Ca Suffit!). Lancet 389, 505-518. doi: 10.1016/S0140-6736(16)32621-6

Huret, C., Desjardins, D., Miyalou, M., Levacher, B., Amadoudji Zin, M., Bonduelle, O., et al. (2013). Recombinant retrovirus-derived virus-like particlebased vaccines induce hepatitis $\mathrm{C}$ virus-specific cellular and neutralizing immune responses in mice. Vaccine 31, 1540-1547. doi: 10.1016/j.vaccine.2012. 05.025

Johnson, K. M., Vogel, J. E., and Peralta, P. H. (1966). Clinical and serological response to laboratory-acquired human infection by Indiana type vesicular stomatitis virus (VSV). Am. J. Trop. Med. Hyg. 15, 244-246. doi: 10.4269/ajtmh. 1966.15.244

Jourdan, N., Godeke, G. J., Penaud, M., Mottola, G., Sorrentino, A., Rottier, P. J., et al. (2006). Assembly of HCV E1 and E2 glycoproteins into coronavirus VLPs - Brief report. Arch. Virol. 151, 2085-2094. doi: 10.1007/s00705-006-0769-0

Kalams, S. A., Parker, S. D., Elizaga, M., Metch, B., Edupuganti, S., Hural, J., et al. (2013). Safety and comparative immunogenicity of an HIV-1 DNA vaccine in combination with plasmid interleukin 12 and impact of intramuscular electroporation for delivery. J. Infect. Dis. 208, 818-829. doi: 10.1093/infdis/ jit236

Kost, T. A., Condreay, J. P., and Jarvis, D. L. (2005). Baculovirus as versatile vectors for protein expression in insect and mammalian cells. Nat. Biotechnol. 23, 567-575. doi: 10.1038/nbt1095

Kretzschmar, E., Buonocore, L., Schnell, M. J., and Rose, J. K. (1997). Highefficiency incorporation of functional influenza virus glycoproteins into recombinant vesicular stomatitis viruses. J. Virol. 71, 5982-5989.

Kumar, A., Das, S., Mullick, R., Lahiri, P., Tatineni, R., Goswami, D., et al. (2016). Immune responses against hepatitis $C$ virus genotype 3 a virus-like particles in mice: a novel VLP prime-adenovirus boost strategy. Vaccine 34, 1115-1125. doi: 10.1016/j.vaccine.2015.11.061

Kunkel, M., Lorinczi, M., Rijnbrand, R., Lemon, S. M., and Watowich, S. J. (2001). Self-assembly of nucleocapsid-like particles from recombinant hepatitis $\mathrm{C}$ virus core protein. J. Virol. 75, 2119-2129. doi: 10.1128/JVI.75.5.2119-2129.2001

Kushnir, N., Streatfield, S. J., and Yusibov, V. (2012). Virus-like particles as a highly efficient vaccine platform: diversity of targets and production systems and advances in clinical development. Vaccine 31, 58-83. doi: 10.1016/j.vaccine. 2012.10.083

Lai, W. B., and Middelberg, A. P. (2002). The production of human papillomavirus type $16 \mathrm{~L} 1$ vaccine product from Escherichia coli inclusion bodies. Bioprocess Biosyst. Eng. 25, 121-128. doi: 10.1007/s00449-002-0289-6

Lechmann, M., Murata, K., Satoi, J., Vergalla, J., Baumert, T. F., and Liang, T. J. (2001). Hepatitis C virus-like particles induce virus-specific humoral and cellular immune responses in mice. Hepatology 34, 417-423. doi: 10.1053/jhep. 2001.26523

Leroux-Roels, G., Esquivel, C. A., DeLeys, R., Stuyver, L., Elewaut, A., Philippé, J., et al. (1996). Lymphoproliferative responses to hepatitis C virus core, E1, E2, and NS3 in patients with chronic hepatitis $\mathrm{C}$ infection treated with interferon alfa. Hepatology 23, 8-16. doi: 10.1002/hep.510230102

Lindenbach, B. D., Evans, M. J., Syder, A. J., Wölk, B., Tellinghuisen, T. L., Liu, C. C., et al. (2005). Complete replication of hepatitis C virus in cell culture. Science 309, 623-626. doi: 10.1126/science. 1114016

Lorenzo, L. J., Dueñas-Carrera, S., Falcón, V., Acosta-Rivero, N., González, E., de la Rosa, M. C., et al. (2001). Assembly of truncated HCV core antigen into viruslike particles in Escherichia coli. Biochem. Biophys. Res. Commun. 281, 962-965. doi: 10.1006/bbrc.2001.4449
Majid, A. M., Ezelle, H., Shah, S., and Barber, G. N. (2006). Evaluating replicationdefective vesicular stomatitis virus as a vaccine vehicle. J. Virol. 80, 6993-7008. doi: 10.1128/JVI.00365-06

Mett, V., Farrance, C. E., Green, B. J., and Yusibov, V. (2008). Plants as biofactories. Biologicals 36, 354-358. doi: 10.1016/j.biologicals.2008.09.001

Mihailova, M., Boos, M., Petrovskis, I., Ose, V., Skrastina, D., Fiedler, M., et al. (2006). Recombinant virus-like particles as a carrier of B- and T-cell epitopes of hepatitis C virus (HCV). Vaccine 24, 4369-4377. doi: 10.1016/j.vaccine.2006. 02.051

Morenweiser, R. (2005). Downstream processing of viral vectors and vaccines. Gene Ther. 12(Suppl. 1), S103-S110. doi: 10.1038/sj.gt.3302624

Murata, K., Lechmann, M., Qiao, M., Gunji, T., Alter, H. J., and Liang, T. J. (2003). Immunization with hepatitis $C$ virus-like particles protects mice from recombinant hepatitis C virus-vaccinia infection. Proc. Natl. Acad. Sci. U.S.A. 100, 6753-6758. doi: 10.1073/pnas.1131929100

Nemchinov, L. G., Liang, T. J., Rifaat, M. M., Mazyad, H. M., Hadidi, A., and Keith, J. M. (2000). Development of a plant-derived subunit vaccine candidate against hepatitis C virus. Arch. Virol. 145, 2557-2573. doi: 10.1007/s007050070008

Netter, H. J., Macnaughton, T. B., Woo, W. P., Tindle, R., and Gowans, E. J. (2001). Antigenicity and immunogenicity of novel chimeric hepatitis B surface antigen particles with exposed hepatitis C virus epitopes. J. Virol. 75, 2130-2141. doi: 10.1128/JVI.75.5.2130-2141.2001

Netter, H. J., Woo, W. P., Tindle, R., Macfarlan, R. I., and Gowans, E. J. (2003). Immunogenicity of recombinant $\mathrm{HBsAg} / \mathrm{HCV}$ particles in mice pre-immunised with hepatitis B virus-specific vaccine. Vaccine 21, 2692-2697. doi: 10.1016/ S0264-410X(03)00182-8

Neumann-Haefelin, C., Blum, H. E., Chisari, F. V., and Thimme, R. (2005). T cell response in hepatitis C virus infection. J. Clin. Virol. 32, 75-85. doi: 10.1016/j. jcv.2004.05.008

Orlova, O. V., Drutsa, V. L., Spirin, P. V., Prasolov, V. S., Rubtsov, P. M., Kochetkov, S. N., et al. (2015). The role of HCV e2 protein glycosylation in functioning of virus envelope proteins in insect and Mammalian cells. Acta Naturae 7, 87-97.

Osburn, W. O., Snider, A. E., Wells, B. L., Latanich, R., Bailey, J. R., Thomas, D. L., et al. (2014). Clearance of hepatitis C infection is associated with the early appearance of broad neutralizing antibody responses. Hepatology 59, 2140-2151. doi: 10.1002/hep.27013

Palomares, L. A., and Ramirez, O. T. (2009). Challenges for the production of viruslike particles in insect cells: the case of rotavirus-like particles. Biochem. Eng. J. 45, 158-167. doi: 10.1016/j.bej.2009.02.006

Patient, R., Hourioux, C., Vaudin, P., Pagès, J. C., and Roingeard, P. (2009). Chimeric hepatitis B and C viruses envelope proteins can form subviral particles: implications for the design of new vaccine strategies. N. Biotechnol. 25, 226-234. doi: 10.1016/j.nbt.2009.01.001

Pestka, J. M., Zeisel, M. B., Bläser, E., Schürmann, P., Bartosch, B., Cosset, F. L., et al. (2007). Rapid induction of virus-neutralizing antibodies and viral clearance in a single-source outbreak of hepatitis C. Proc. Natl. Acad. Sci. U.S.A. 104, 6025-6030. doi: 10.1073/pnas.0607026104

Prince, A. M. (1994). Immunity in hepatitis C virus infection. Vox Sang. 67(Suppl. 3), 227-228. doi: 10.1111/j.1423-0410.1994.tb04581.x

Regules, J. A., Beigel, J. H., Paolino, K. M., Voell, J., Castellano, A. R., Hu, Z., et al. (2017). A recombinant vesicular stomatitis Virus Ebola vaccine. N. Engl. J. Med. 376, 330-341. doi: 10.1056/NEJMoa1414216

Rioux, G., Babin, C., Majeau, N., and Leclerc, D. (2012). Engineering of papaya mosaic virus (PapMV) nanoparticles through fusion of the HA11 peptide to several putative surface-exposed sites. PLOS ONE 7:e31925. doi: 10.1371/ journal.pone. 0031925

Rosa, D., Campagnoli, S., Moretto, C., Guenzi, E., Cousens, L., Chin, M., et al. (1996). A quantitative test to estimate neutralizing antibodies to the hepatitis C virus: cytofluorimetric assessment of envelope glycoprotein 2 binding to target cells. Proc. Natl. Acad. Sci. U.S.A. 93, 1759-1763. doi: 10.1073/pnas.93.5.1759

Rosenthal, E. S., and Graham, C. S. (2016). Price and affordability of direct-acting antiviral regimens for hepatitis $\mathrm{C}$ virus in the United States. Infect. Agent Cancer 11:24. doi: 10.1186/s13027-016-0071-z

Roy, P., and Noad, R. (2008). Virus-like particles as a vaccine delivery system: myths and facts. Hum. Vaccin. 4, 5-12. doi: 10.4161/hv.4.1.5559

Roy, P., and Noad, R. (2009). Virus-like particles as a vaccine delivery system: myths and facts. Adv. Exp. Med. Biol. 655, 145-158. doi: 10.1007/978-1-44191132-2_11 
Rybicki, E. P. (2014). Plant-based vaccines against viruses. Virol. J. 11:205. doi: 10.1186/s12985-014-0205-0

Santi, L., Batchelor, L., Huang, Z., Hjelm, B., Kilbourne, J., Arntzen, C. J., et al. (2008). An efficient plant viral expression system generating orally immunogenic Norwalk virus-like particles. Vaccine 26, 1846-1854. doi: 10.1016/j.vaccine.2008.01.053

Schnell, M. J., Buonocore, L., Kretzschmar, E., Johnson, E., and Rose, J. K. (1996). Foreign glycoproteins expressed from recombinant vesicular stomatitis viruses are incorporated efficiently into virus particles. Proc. Natl. Acad. Sci. U.S.A. 93, 11359-11365. doi: 10.1073/pnas.93.21.11359

Sominskaya, I., Skrastina, D., Dislers, A., Vasiljev, D., Mihailova, M., Ose, V., et al. (2010). Construction and immunological evaluation of multivalent hepatitis B virus (HBV) core virus-like particles carrying HBV and HCV epitopes. Clin. Vaccine Immunol. 17, 1027-1033. doi: 10.1128/CVI.00468-09

Thimme, R., Bukh, J., Spangenberg, H. C., Wieland, S., Pemberton, J., Steiger, C., et al. (2002). Viral and immunological determinants of hepatitis C virus clearance, persistence, and disease. Proc. Natl. Acad. Sci. U.S.A. 99, 15661-15668. doi: 10.1073/pnas.202608299

Thimme, R., Oldach, D., Chang, K. M., Steiger, C., Ray, S. C., and Chisari, F. V. (2001). Determinants of viral clearance and persistence during acute hepatitis C virus infection. J. Exp. Med. 194, 1395-1406. doi: 10.1084/jem.194.10.1395

Torresi, J., Fischer, A., Grollo, L., Zeng, W., Drummer, H., and Jackson, D. C. (2007). Induction of neutralizing antibody responses to hepatitis C virus with synthetic peptide constructs incorporating both antibody and T-helper epitopes. Immunol. Cell Biol. 85, 169-173. doi: 10.1038/sj.icb.7100021

Tremblay, M. H., Majeau, N., Gagné, M. E., Lecours, K., Morin, H., Duvignaud, J. B., et al. (2006). Effect of mutations K97A and E128A on RNA binding and self assembly of papaya mosaic potexvirus coat protein. FEBS J. 273, 14-25. doi: 10.1111/j.1742-4658.2005.05033.x

Ulrich, R., Borisova, G. P., Gren, E., Berzin, I., Pumpen, P., Eckert, R., et al. (1992). Immunogenicity of recombinant core particles of hepatitis $\mathrm{B}$ virus containing epitopes of human immunodeficiency virus 1 core antigen. Arch. Virol. 126, 321-328. doi: 10.1007/BF01309705

Ulrich, R., Nassal, M., Meisel, H., and Krüger, D. H. (1998). Core particles of hepatitis B virus as carrier for foreign epitopes. Adv. Virus Res. 50, 141-182. doi: 10.1016/S0065-3527(08)60808-8

van Oers M. M., Pijlman, G. P., and Vlak, J. M. (2015). Thirty years of baculovirusinsect cell protein expression: from dark horse to mainstream technology. J. Gen. Virol. 96(Pt 1), 6-23. doi: 10.1099/vir.0.067108-0

Vicente, T., Roldão, A., Peixoto, C., Carrondo, M. J., and Alves, P. M. (2011). Largescale production and purification of VLP-based vaccines. J. Invertebr. Pathol. 107(Suppl.), S42-S48. doi: 10.1016/j.jip.2011.05.004

Vietheer, P. T., Boo, I., Drummer, H. E., and Netter, H. J. (2007). Immunizations with chimeric hepatitis B virus-like particles to induce potential anti-hepatitis $\mathrm{C}$ virus neutralizing antibodies. Antivir. Ther. 12, 477-487.
Wakita, T., Pietschmann, T., Kato, T., Date, T., Miyamoto, M., Zhao, Z., et al. (2005). Production of infectious hepatitis $C$ virus in tissue culture from a cloned viral genome. Nat. Med. 11, 791-796. doi: 10.1038/nm1268

Wellnitz, S., Klumpp, B., Barth, H., Ito, S., Depla, E., Dubuisson, J., et al. (2002). Binding of hepatitis $\mathrm{C}$ virus-like particles derived from infectious clone $\mathrm{H} 77 \mathrm{C}$ to defined human cell lines. J. Virol. 76, 1181-1193. doi: 10.1128/JVI.76.3.11811193.2002

World Health Organization (2017). Global Hepatitis Report 2017. Geneva: World Health Organization.

Yoshikawa, A., Tanaka, T., Hoshi, Y., Kato, N., Tachibana, K., Iizuka, H., et al. (1993). Chimeric hepatitis B virus core particles with parts or copies of the hepatitis C virus core protein. J. Virol. 67, 6064-6070.

Youn, J. W., Park, S. H., Lavillette, D., Cosset, F. L., Yang, S. H., Lee, C. G., et al. (2005). Sustained E2 antibody response correlates with reduced peak viremia after hepatitis $C$ virus infection in the chimpanzee. Hepatology 42, 1429-1436. doi: 10.1002/hep.20934

Yu, M. Y., Bartosch, B., Zhang, P., Guo, Z. P., Renzi, P. M., Shen, L. M., et al. (2004). Neutralizing antibodies to hepatitis $\mathrm{C}$ virus (HCV) in immune globulins derived from anti-HCV-positive plasma. Proc. Natl. Acad. Sci. U.S.A. 101, 7705-7710. doi: 10.1073/pnas.0402458101

Yusibov, V., and Rabindran, S. (2008). Recent progress in the development of plant derived vaccines. Expert Rev. Vaccines 7, 1173-1183. doi: 10.1586/14760584.7. 8.1173

Zhang, W., Carmichael, J., Ferguson, J., Inglis, S., Ashrafian, H., and Stanley, M. (1998). Expression of human papillomavirus type $16 \mathrm{~L} 1$ protein in Escherichia coli: denaturation, renaturation, and self-assembly of virus-like particles in vitro. Virology 243, 423-431. doi: 10.1006/viro.1998.9050

Zhao, W., Liao, G. Y., Jiang, Y. J., and Jiang, S. D. (2004). Expression and self-assembly of HCV structural proteins into virus-like particles and their immunogenicity. Chin. Med. J. 117, 1217-1222.

Zhong, J., Gastaminza, P., Cheng, G., Kapadia, S., Kato, T., Burton, D. R., et al. (2005). Robust hepatitis C virus infection in vitro. Proc. Natl. Acad. Sci. U.S.A. 102, 9294-9299. doi: 10.1073/pnas.0503596102

Conflict of Interest Statement: The authors declare that the research was conducted in the absence of any commercial or financial relationships that could be construed as a potential conflict of interest.

Copyright (c) 2017 Masavuli, Wijesundara, Torresi, Gowans and Grubor-Bauk. This is an open-access article distributed under the terms of the Creative Commons Attribution License (CC BY). The use, distribution or reproduction in other forums is permitted, provided the original author(s) or licensor are credited and that the original publication in this journal is cited, in accordance with accepted academic practice. No use, distribution or reproduction is permitted which does not comply with these terms. 